\title{
A LOCAL CENSUS.
}

BY WM. LOVELL HUNTER, M.D., D.P.H., Medical Officer of Health for the Borough of Pudsey.

THE information to be gained from the vital or health statistics of a district is of great importance, and, as these statistics are based on the number of the population, it is essential for the accuracy of the statistics that the number of people living in the place should be known as exactly as possible; for example, if the number of the population is overestimated, the death-rate will appear better than it really is, and on the other hand, if an under-estimation is made, the death-rate will be wrongly exaggerated. Up to the present a census, or official counting of the population, of each locality in Great Britain is taken every ten years; and for the years between the census years an estimate only of the population can be made. This interval is now acknowledged to be too long, and the necessity for more frequent enumerations has been shown by the great mistakes made in calculating the population of many places between the census years. In some countries the census is taken more frequently-every five years in Denmark and France, every three years in Prussia and Belgium, and every year in Austria. London took its first quinquennial local census in 1896 .

A local census also gives valuable information as to the population of parts of the district.

This is the Second Local Census of Pudsey. The first was made in 1896.

The following notes may be of interest, and useful for future undertakings of the same kind.

The Corporation, at a meeting held March 21st, 1906, on the recommendation of the Sanitary Committee, sanctioned the taking of a modified census of the town. As it was necessary to limit the expense, it was decided to ascertain only the population of each house, distinguishing those below and above five years of age, and in addition, to note the number of uninhabited houses.

Books, having twenty lines on each page, with the following printed headings, were used:-

\begin{tabular}{|c|c|c|c|c|c|}
\hline $\begin{array}{l}\text { No. of } \\
\text { House. }\end{array}$ & Street. & aceupier. & $\begin{array}{c}\text { Total } \\
\text { Number } \\
\text { in House. }\end{array}$ & $\begin{array}{l}\text { Number } \\
\text { under five } \\
\text { years of } \\
\text { age. }\end{array}$ & $\begin{array}{l}\text { Number } \\
\text { above five } \\
\text { years of } \\
\text { age. }\end{array}$ \\
\hline
\end{tabular}

No papers were left at the houses, the facts being inserted directly into the books by the enumerators-one enumerator counted each ward.

Dwelling-houses only were counted; no notice was taken of lock-up shops, workshops, etc.

From the result it is evident that a modified, yet accurate and useful, census of a town the size of Pudsey, can be taken without undue expense, and frequently enough, amongst other advantages, to ensure the accuracy of the health statistics.

The information obtained from this census fully justifies the taking of 
it. It shows that the estimation of the population-made in the usual way-was altogether wrong, being much too great. The estimated population for the middle of the present year was 15,179, 1622 in excess of that shown by the count. Figures based on such an erroneous estimate are obviously incorrect and seriously misleading. This estimation was made from year to year, and to a great extent, was based on the excess of births over deaths-what is termed the natural increase. The real cause of the serious shrinkage in population was probably emigration due to trade conditions, and the number of the population so affected can only be gauged by actual counting. The voters' lists give some indication that the shrinkage in population began about three years ago.

\title{
THE KEEPING OF POULTRY IN CLOSE PROXIMITY TO HOUSES.*
}

\author{
BY J. T. C. NASH, M.D., D.P.H., \\ Medical Officer of Health for Southend-on-Sea.
}

ANOTHER measure which I am inclined to think would be of material assistance in the prevention of diarrhoea would be additional legal powers in connection with the keeping of poultry and other animals in small terrace gardens in congested districts of the town.

A very considerable number of persons who live in small terraced houses in the poorer parts of the town keep fowls, and often breed them. In some instances the back yard is practically converted into a fowl run.

As is well known, birds are constantly excreting, and more constantly scratching the surface soil. Consequently it is not difficult to see that-in hot dusty weather-a considerable number of Bacillus coli communis (and other objectionable germs) must find their way through open doors and windows into the larder and kitchen, which abut upon the back yard.

Legislation should provide for-

(1) Prohibiting the keeping of poultry in crowded districts unless the owners conform to certain regulations.

(2) Limiting the number of animals (birds and other kinds of animals) kept on any inhabited premises.

(3) Requiring that no poultry run shall be permitted within 25 feet of inhabited premises.

(4) Requiring periodical cleansing of the fowl roost and fowl run.

(5) Penalties.

The keeping of poultry in small back yards in towns should certainly be discouraged. It is good neither for the birds nor for their human owners to have them confined in small runs in close proximity to numerous dwelling-houses.

I have not as yet sufficient data to enable me to estimate any probable degree of prejudice to health through the keeping of animals in confined back yards; but I think it must be sufficiently obvious that the circumstances of life under such conditions can hardly be-termed quite sanitary.

$$
\text { * Annual Report, 1904. }
$$

